\title{
Population Dynamics and Convergence in Fertility Rates ${ }^{1}$
}

\author{
Tryggvi Thor Herbertsson², J. Michael Orszag ${ }^{3}$ \\ and Peter R. Orszag 4 .
}

\begin{abstract}
Empirical studies of per capita income convergence across countries have proliferated in the past decade. The purpose of this paper is to build upon that literature by examining demographic, rather than economic, convergence. In this paper, we examine whether fertility rates have been converging across countries. Our results indicate that fertility rates are indeed converging both absolutely and conditionally. Furthermore the dispersion of fertility rates also seems to be falling, indicating the presence of sigma convergence. A simple model is presented which suggests that this might be an artifact of transitional effects of later childbearing, rather than a slowdown of long-run fertility rates.
\end{abstract}

\section{Ágrip}

Alpjóðlegar rannsóknir á samleitni pjóðartekna (mælt á hvern íbúa) hafa aukist verulega á síðustu áratugum. Í pessari grein er byggt á aðferðafræði pessara rannsókna en í stað pess að skoða samleitni pjóðartekna á mann er lýðfræðileg samleitni skoðuð, nánar tiltekið fæðingartíðni. Í greininni er skoðað hvort frjósemi hefur náð sambærilegum stigum milli landa. Niðurstöður okkar benda til pess að frjósemishlutföll sýni samleitni. Ennfremur virðist dreifing frjósemi minnkandi. Kynnt er til sögunnar einfalt líkan sem sýnir að petta gæti helgast af tilfærsluáhrifum vegna síðbúinna barneigna, frekar en pví að dregið hafi úr frjósemi.

JEL flokkun: J11; J13

Lykil hugtök: Demography, Fertility rates, Convergence.

\footnotetext{
${ }^{1}$ The authors want to thank (without implicating) Ron Smith and Dennis Snower and two anonymous referees for valuable comments and discussions.

2 Institute of Economic Studies, University of Iceland, Aragata 14, 101 Reykjavik, Iceland, phone: (+354) 525 4535, fax: (+354) 552 6806, e-mail: tthh@hi.is.

${ }^{3}$ Watson Wyatt, Watson House, London Road, Reigate, Surrey RH2 9PQ, UK, phone: +44 1737 241144, fax: +44 1737 241496, e-mail: michael.orszag@eu.watsonwyatt.com.

4 The Brookings Institution, 1775 Massachusetts Ave NW, Washington DC 20036, USA, phone: (202) 797-6163, fax: (202) 797-6181.
} 


\section{Introduction}

Empirical studies of per capita income convergence across countries have proliferated in the past decade, following the seminal work of Baumol (1986), Barro (1991), and others. ${ }^{5}$ The purpose of this paper is to build upon that literature by examining demographic, rather than economic convergence. In particular, our focus is whether population dynamics are tending to become more similar across countries. The issue is an important one, since the relative size of countries has economic and political ramifications ranging from financial investment strategies to the optimal design of pension systems and even military and political relationships. ${ }^{6}$ In addition, studying demographic convergence can further contribute to our understanding of economic convergence (or lack thereof), since demographics are both affected by, and affect, income. Beginning with Malthus, a large literature has explored the connections between economic variables and fertility and mortality as well as with net migration. ${ }^{7}$

A substantial literature exists on the economics of fertility. This literature focuses on the demand for children, the relationship between fertility and female labour force participation, and a variety of other related issues. ${ }^{8}$ However, to our knowledge, international convergence in fertility rates has not been extensively researched. In this paper, we examine whether fertility rates have been converging across countries. A separate question is whether mortality rates are converging across countries. If fertility and mortality rates were the same across countries, and assuming identical age distributions and no migration, the cross-country pattern of populations would be propagated through time - and each country's population dynamics would mirror the world's population dynamics. More complicated dynamic processes emerge when, as in the real world, initial conditions involve differential fertility rates, mortality rates, and age distributions across countries. ${ }^{9}$ The specific question we address here is: Are fertility rates tending to converge across countries? ${ }^{10}$ If not, what factors can help to explain differential changes in fertility rates?

The economic growth literature defines two types of convergence: absolute and conditional. Absolute convergence means that all countries will eventually grow at the same rate. In the context of our analysis, this would mean that all countries would eventually have the same fertility rate regardless of other factors. With

\footnotetext{
${ }^{5}$ For summaries of the burgeoning literature on convergence with respect to income per capita, see Barro and Sala-i-Martin (1995), Baumol, Blackman, and Wolff (1989), and Herbertsson (1999).

${ }^{6}$ For the potential importance of population in military and political relationships, see Kennedy (1987), p. 198-202.

7 See, for example, Leibenstein, (1994), Easterlin (1966), Becker (1960), and Wahl (1985). For a recent model of endogenous fertility, see Barro and Sala-i-Martin, op. cit., Ch. 9.

8 The literature on the economics of fertility is surveyed in Holtz, Klerman, and Willis (1997) and Schultz (1997).

9 For an introduction to demographic mathematics, see Keyfitz (1977).

10 The growth literature has generated several definitions of "convergence." We refer to convergence in the beta-convergence sense. For a criticism of beta convergence, see Quah (1993).
} 
conditional convergence, all countries grow to their own steady state, which depends on underlying country-specific economic factors. Because fertility and mortality depend on economic factors in our analysis, our approach is to utilize this latter approach of conditional convergence to separate out economic and demographic effects.

\section{Behavior of Fertility Rates Across Countries}

To examine the evolution of fertility rates across countries, we use demographic and economic data from the World Health Organization, ${ }^{11}$ the Penn World Tables, and Barro and Lee (1993). The data cover more than 190 countries (not all countries have complete data). Appendix A describes the variables used in this study.

Figures 1 and 2 show histograms of fertility rates across countries in 1978 and 1998. As the figures show, a significant shift of probability mass has occurred from higher to lower fertility rates over that period. In 1978, only 37 per cent of countries in the sample had a total fertility rate below 4 . By 1998, the proportion of countries with fertility rates below this level had increased to 61 per cent. We also note that the mean fertility rate fell from 4.7 in 1978 to 3.5 in 1998.

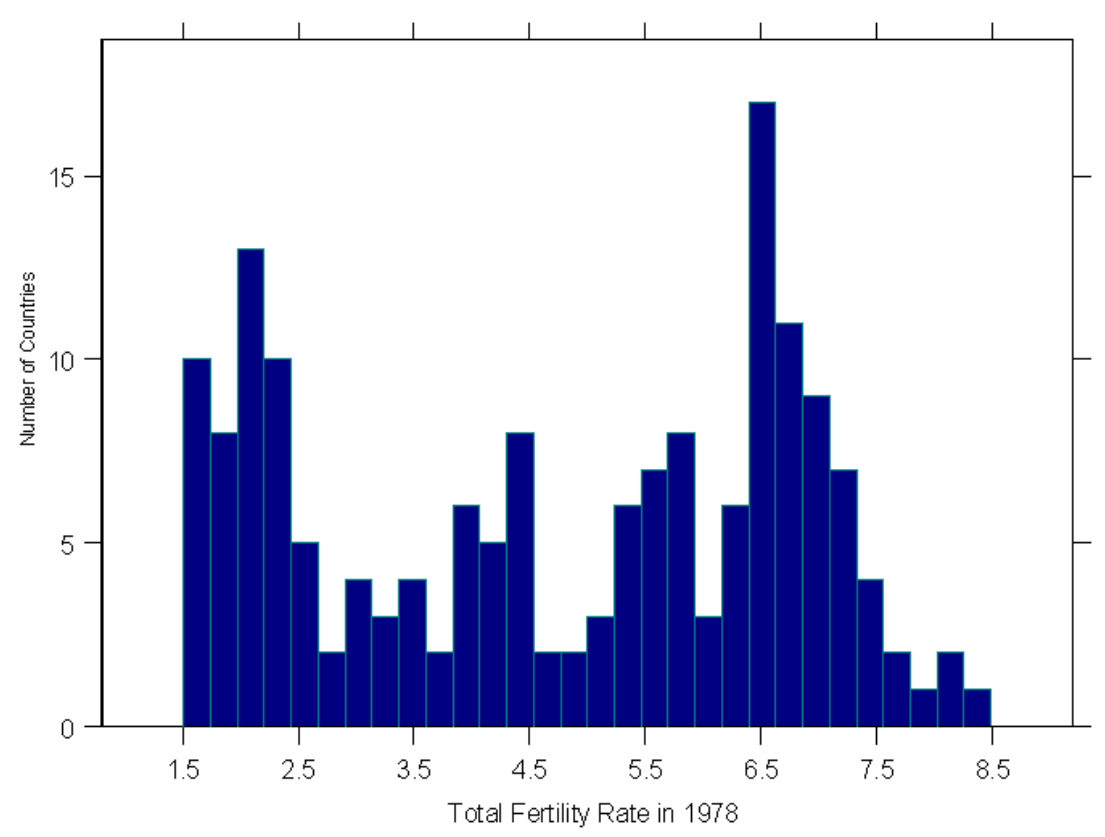

Figure 1. The Distribution of Fertility Rates Across Countries, 1978.

${ }^{11}$ Available on-line at http:/ / www.who.org. 


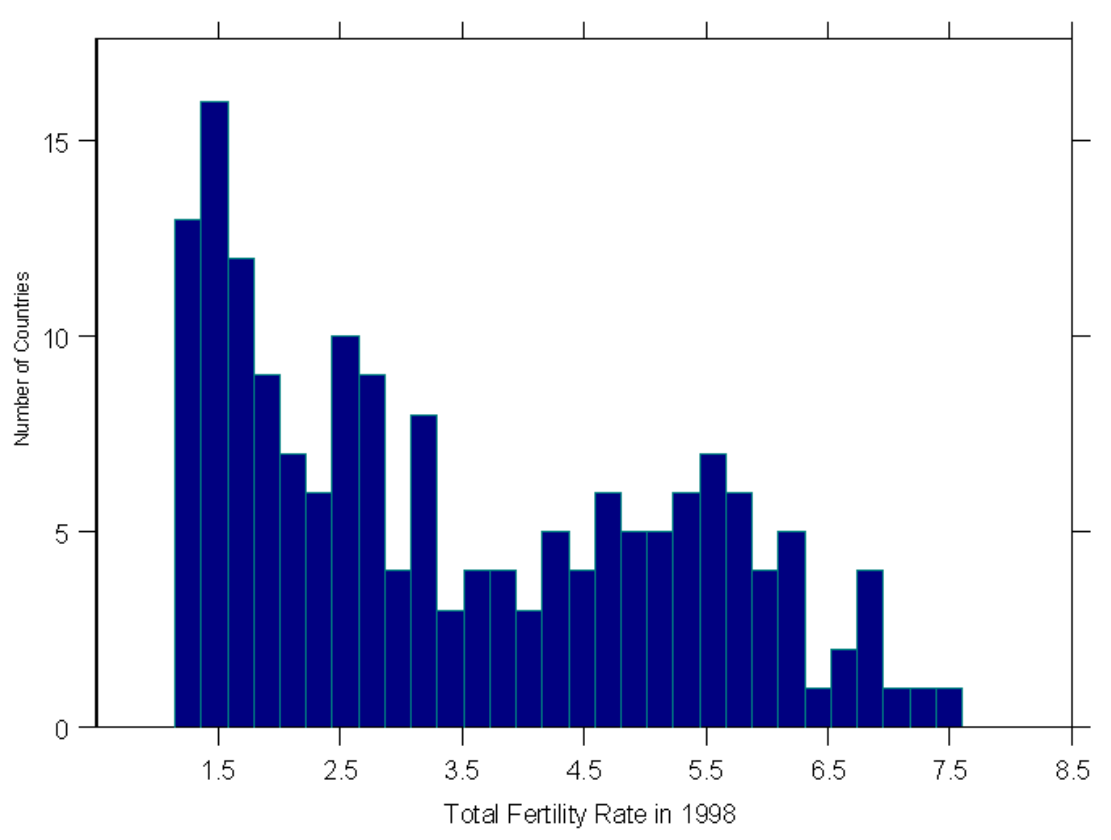

Figure 2. The Distribution of Fertility Rates Across Countries, 1998.

The secular decline in fertility rates over time highlighted by Figures 1 and 2 has been examined by numerous other authors. ${ }^{12}$ We do not repeat those analyses, which focus more on the time series behavior of fertility rates within a country than on the distribution of fertility rates across countries. Instead, our focus is whether the ongoing decline in fertility rates has occurred differentially across countries, and, if so, what factors could best explain the cross-country differentials.

The first step is a simple comparison of the change in fertility rates (the 1998 rate minus the 1978 rate) with the 1978 fertility rate. Figure 3 shows that countries with high fertility rates in 1978 experienced larger declines in fertility between 1978 and 1998 than countries with lower fertility rates in 1978, lending support to our hypothesis. In addition, the standard deviation of fertility rates across countries declined from 2.02 in 1978 to 1.77 in $1998 .{ }^{13}$

12 For a summary of the literature on the secular decline in fertility rates, see Easterlin (1989) and references therein.

${ }^{13}$ The decline in the standard deviation of fertility rates is suggestive of so-called sigmaconvergence, which examines whether the distribution of fertility rates tends to be narrowing or expanding across countries. For further discussion of sigma-convergence, and its potential biases, see Quah (1993). 


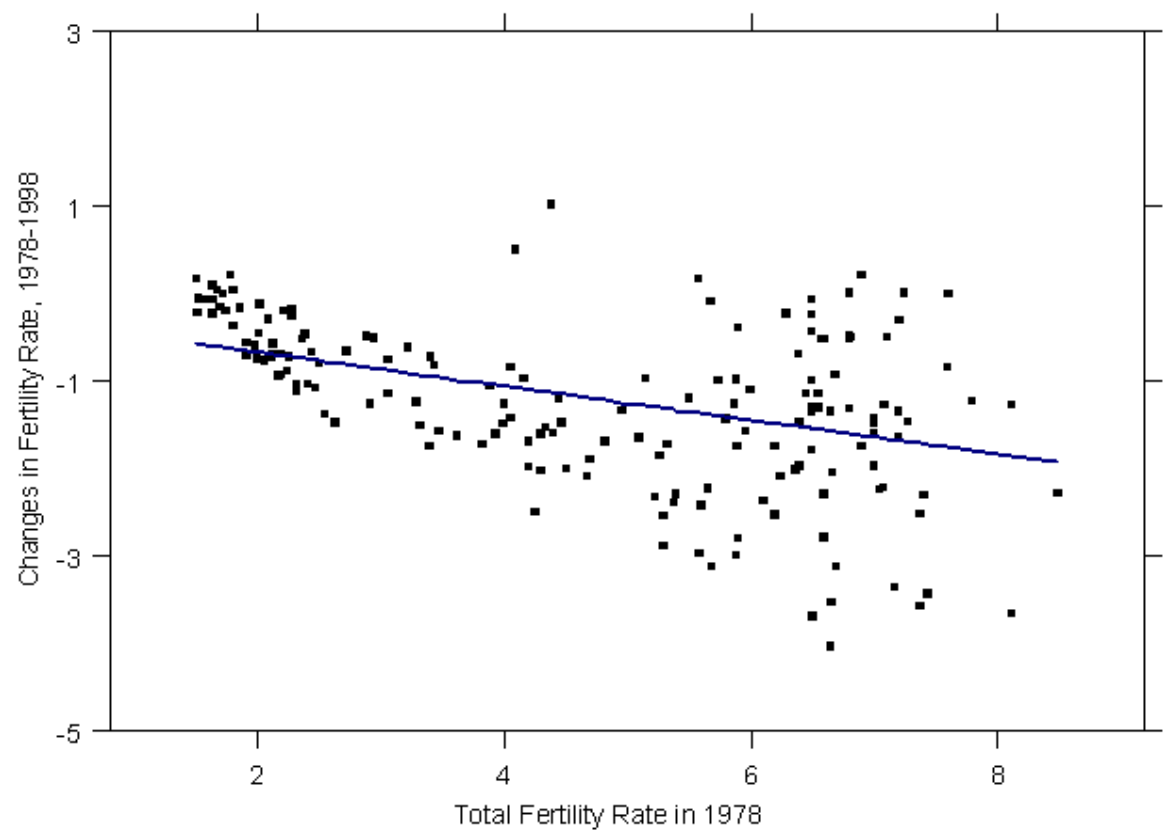

Figure 3. The Relationship Between Initial Total Fertility Rates and Subsequent Changes, 1978-98.

\section{Analysis of Fertility Rates Across Countries}

We now turn to investigating whether the negative relationship between the change in fertility rates and the base fertility rate in 1978 (as shown in Figure 3) is robust in more formal analyses. To undertake this investigation, we apply the well-known convergence framework, i.e., we postulate that fertility rates in the world are converging to a common one, either absolutely or conditioned on various country specific demographic and economic factors. Table 1 reports our regression results. ${ }^{14}$

14 Cf. Lee, Pesaran, and Smith (1997) and Temple (1998) for a critical review of cross-sectional growth regressions like the one applied here. 
Table 1. Dependent variable, changes in fertility rates, 1978-98.

\begin{tabular}{|c|c|c|c|c|c|c|c|c|c|c|c|}
\hline & (1) & (2) & (3a) & (3b) & (4) & (5a) & (5b) & (6) & (7) & (8) & (9) \\
\hline \multirow[t]{2}{*}{ TFR78 } & -0.23 & -0.22 & -0.22 & 0.29 & 0.22 & $\begin{array}{c}-0.50 \\
\end{array}$ & -0.24 & -0.39 & -0.21 & -0.23 & -0.22 \\
\hline & (7.25) & (5.93) & (3.80) & (5.12) & $(4.07)$ & (8.51) & (4.29) & (3.21) & $(1.30)$ & (1.41) & (1.31) \\
\hline \multirow[t]{2}{*}{ IMRDIFF } & - & 0.00 & 0.01 & 0.01 & 0.01 & 0.01 & 0.00 & 0.01 & 0.01 & 0.02 & 0.02 \\
\hline & - & $(0.32)$ & (2.58) & (3.22) & (2.03) & (3.66) & $(0.01)$ & (3.74) & (3.67) & (3.72) & (4.11) \\
\hline \multirow[t]{2}{*}{ Log GDP78 } & - & - & -0.19 & - & -0.78 & -0.13 & -0.73 & -0.13 & -0.45 & -0.43 & -0.65 \\
\hline & - & - & $(1.76)$ & - & $(4.23)$ & $(0.74)$ & (3.90) & $(0.73)$ & (2.16) & (2.05) & (2.85) \\
\hline \multirow[t]{2}{*}{ GDPGR8292 } & - & - & - & -0.15 & - & - & - & - & - & - & - \\
\hline & - & - & - & (3.39) & - & - & - & - & - & - & - \\
\hline \multirow[t]{2}{*}{ Africa } & - & - & - & - & 0.00 & 0.00 & 0.00 & 0.00 & 0.00 & 0.00 & 0.00 \\
\hline & - & - & - & - & (3.85) & (2.71) & (3.79) & (2.43) & (2.43) & (2.28) & (2.44) \\
\hline \multirow[t]{2}{*}{ LEB78 } & - & - & - & - & - & -0.09 & - & -0.09 & -0.05 & -0.04 & -0.03 \\
\hline & - & - & - & - & - & (7.48) & - & $(6.02)$ & (2.55) & (2.37) & (1.66) \\
\hline \multirow[t]{2}{*}{ LEBDIFF } & - & - & - & - & - & - & -0.03 & - & - & - & - \\
\hline & - & - & - & - & - & - & (1.43) & - & - & - & - \\
\hline \multirow[t]{2}{*}{ DPR78 } & - & - & - & - & - & - & - & -0.01 & -0.03 & -0.03 & -0.02 \\
\hline & - & - & - & - & - & - & - & (1.01) & (2.06) & (1.99) & (1.89) \\
\hline \multirow[t]{2}{*}{ SEC78 } & - & - & - & - & - & - & - & - & 0.01 & -0.01 & -0.05 \\
\hline & - & - & - & - & - & - & - & - & $(0.02)$ & $(0.01)$ & $(0.08)$ \\
\hline \multirow[t]{2}{*}{ Investment } & - & - & - & - & - & - & - & - & - & -1.17 & -1.87 \\
\hline & - & - & - & - & - & - & - & - & - & $(0.96)$ & (1.34) \\
\hline \multirow[t]{2}{*}{ HEALTH78 } & - & - & - & - & - & - & - & - & - & - & 0.06 \\
\hline & - & - & - & - & - & - & - & - & - & - & (1.69) \\
\hline \multirow[t]{2}{*}{ Constant } & -0.16 & -0.16 & 1.64 & 0.69 & 5.51 & 7.71 & 5.19 & 7.62 & 8.11 & 8.06 & 8.98 \\
\hline & $(1.01)$ & $(1.01)$ & $(1.64)$ & (2.69) & (3.92) & $(6.72)$ & (3.66) & $(6.29)$ & (5.62) & (5.56) & (5.79) \\
\hline \# Countries & 171 & 171 & 130 & 87 & 130 & 130 & 130 & 130 & 91 & 92 & 72 \\
\hline $\mathrm{SE}$ & 0.84 & 0.84 & 0.81 & 0.74 & 0.77 & 0.74 & 0.77 & 0.64 & 0.59 & 0.59 & 0.54 \\
\hline$R^{2}$ & 0.24 & 0.24 & 0.28 & 0.49 & 0.36 & 0.56 & 0.34 & 0.56 & 0.60 & 0.60 & 0.70 \\
\hline
\end{tabular}

Column (1) reports what we refer to as an unconditional convergence regression of fertility rates, and thereby formalizes the results from Figure 3. The negative coefficient on total fertility in 1978 (TFR78) shows that countries that had high total fertility rates in 1978 have had more substantial declines in fertility rates than countries with low initial fertility rates, providing evidence that fertility rates might be converging to a common one. Columns (2) to (9) show conditional convergence regressions that include, in addition to the initial fertility rate in 1978, various demographic and economic variables thought to explain changes in fertility rates in the period under scrutiny. The reminder of this section describes the results obtained in further detail by discussing the impact of each control variable.

Initial total fertility (TFR78): The coefficient on this variable represents convergence in total fertility rates across countries. The coefficient appears with the expected negative sign in all the regressions. The negative coefficients are statistically significant at the 5 per cent level, except in regressions (7) through (9). As mentioned above, regression (1) suggests absolute convergence in fertility rates across countries, i.e., fertility rates in countries with high initial rates are declining faster than in countries with low initial rates. The inclusion of additional variables does not seem to alter this result. The regression parameter remains surprisingly stable at -0.22 to 0.23 (except in regressions (5) and (6)). ${ }^{15} \mathrm{~A}$ coefficient of -0.23 indicates that countries approach their steady-state fertility rate at the speed of 2.3 per cent per annum, which means that a particular county would half the gap from its steady-state fertility rate in approximately 30 years. As a matter of fact the average total fertility

\footnotetext{
15 We also ran regression (1), now using the logs of initial total fertility rate as a regressor instead of the change in the fertility rate, but that did not alter the results.
} 
rate in the sample declined from 4.72 to 3.47 or by 36 per cent from 1978 to 1998, indicating an average annual decline of approximately 1.8 per cent. Applying this figure to a particular country would half the gap in 38 years compared with 30 years implied by the estimation.

Changes in infant mortality (IMRDIFF): A decline in infant mortality should induce women to have fewer infants, more of whom then survive to childhood. We therefore include changes in infant mortality in our regression. According to regression (2), this hypothesis seems not to be supported - the IMRDIFF variable enters with a zero coefficient. When we add the logarithm of initial GDP, however, the coefficient becomes slightly positive and statistically significant. The mean infant mortality rate in 1978 was 78 per 1,000 children, and the mean change in the infant mortality rate between 1978 and 1998 was -27. A decline of 27 deaths per 1,000 children, according to the regressions, would reduce the total fertility rate by approximately 0.3 to 0.6 per female, or roughly 10 per cent of the mean total fertility rate in 1978 of 4.7 births per female. ${ }^{16}$

Initial GDP per capita, adjusted for PPP (Log GDP78): Smith (1999) summarizes the literature suggesting higher incomes are associated with better health (and thereby longevity), although the direction of the causality is not certain. Also, authors such as Barro and Becker (1988) claim that the opportunity cost of raising children increases with income, so that fertility rates decline as income increases. We include the logarithm of initial GDP per capita, evaluated at purchasing power parity (PPP) exchange rates. The hypothesis is supported in most of our regressions. One potential problem with these results is that the existing literature links fertility rates with income levels, yet our reported regression links the change in fertility rates with income levels. We therefore also ran regressions replacing the level of GDP per capita with the average annual growth rate of GDP per capita between 1982 and 1992 (cf., regression (3b)). Using the growth rate in GDP per capita rather than the level did not alter the results significantly (although data limitations reduced the number of countries included in the regression from 130 to 87). A potential problem with using the growth rate rather than the level is endogeneity; in our primary regressions, we therefore retain the initial level of GDP per capita rather than the growth rate.

Dummy variable for Africa (AFRICA): To investigate if changes in fertility rates could be explained be regional differences, we regressed changes in total fertility rates on the initial fertility rate and six continental dummies (not reported). All the continent dummies were insignificant except for the Africa dummy, indicating that population dynamics may be different in Africa than in other continents. We therefore included a dummy variable for Africa in regressions (4) through (9). The Africa effect is small but statistically significant in all the regressions, indicating that conditional on all the other variables, fertility has not declined in Africa as rapidly as the rest of the world.

\footnotetext{
${ }^{16}$ This variable, however, is potentially endogenous: Lower infant mortality rates may induce women to have fewer infants and thereby reduce the total fertility rate, but a lower fertility rate may also reduce the infant mortality rate, e.g., if lower fertility rates imply that older or less healthy women are less likely to have infants. As noted below in Section 4, lower observed fertility rates can also be due to women delaying childbirth.
} 
Initial life expectancy at birth (LEB78): Life expectancy at birth should, among other things, reflect the probability of newborns surviving to adulthood. As with infant mortality, increased life expectancy may, ceteris paribus, be reflected in decreased fertility rates. To test this hypothesis we added initial life expectancy to our regressions. The coefficient is statistically significant and appears with the right sign. We also ran the regression using the change in life expectancy 1978-98, as a regressor (cf., regression (5b)). The variable still appeared with the right sign, but its coefficient was statistically insignificant from zero. (The change in life expectancy suffers from similar endogeneity problems to the growth rate in real GDP per capita. We therefore retained the initial level of life expectancy in our primary regressions.)

Initial dependency ratio (DPR78): The higher the dependency ratio, defined as population under 15 plus 65 and over per 100 people aged 15-64, the more we may expect fertility rates to decline (in order to reduce the dependency ratio). The coefficient on this variable is statistically significant in regressions (7) to (9) but not when the education variable is excluded, see regression (6).

Initial education (SEC78): It has been postulated that the best way to reduce fertility in the developing countries is to increase education among woman. Higher education levels, according to these arguments, would raise female wages and consequently the opportunity costs of having babies, cf. World Bank (1993). To test the cross-country impact of education levels on the decline in fertility rates, we added a proxy for education - secondary school enrollment. The coefficient on this variable, however, was statistically insignificant. Insignificant coefficient estimates for education are also commonplace in the growth literature (Herbertsson, 1999).

Investment in physical capital: Higher investment in physical capital should raise the marginal product of labor, and therefore, ceteris paribus, make additional children a more attractive opportunity. But the coefficient on the investment-GDP ratio was statistically insignificant, indicating that investment does not affect changes in fertility.

Public health spending: The last variable we include in our regressions is public spending on health care as a proportion of GDP. The hypothesis is that the more a country spends on health care, the less infant mortality there is, the higher the life expectancy, and consequently, the lower the fertility rate is. Furthermore, even conditional on infant mortality and life expectancy, a higher level of public health care spending may serve as a proxy for other variables affecting fertility rates. We therefore included public spending on health care as a percentage of GDP in addition to our other variables. Its coefficient was statistically significant but appears with a positive sign (i.e., those countries with higher public health care spending experienced a slower decline in fertility rates).

\section{Convergence and Transitional Fertility Dynamics}

We thus find substantial evidence for convergence in fertility rates. But this result may be an artifact of a transition in fertility: women are getting older as they have children. In Appendix C, we outline a very simple model to show that transitional fertility rates can dip below their steady state values as women delay childbearing due to, e.g., increased education or work commitments. The dynamics are 
complicated because even in a new steady state - which may not even obtain - the fertility rate could be lower than in the previous steady state. The intuition for this effect is that the population at the new, older childbearing age is smaller than the younger age at which women traditionally had babies (because of an increasing probability of death as age increases). The same rate of birth (that is, living women have the same number of children as they did at younger ages) from this new lower population will therefore result in a smaller number of newborn babies.

One can illustrate these points by a simple simulation. We assumed the entire population had the long-run demographic characteristics of English Life Tables 15 for females, where each 24-year old person had 1.05 children initially. The total fertility ratio (births to population aged 20-40 in our simulations) was approximately 5 per cent. Figure 4 shows the dynamics.

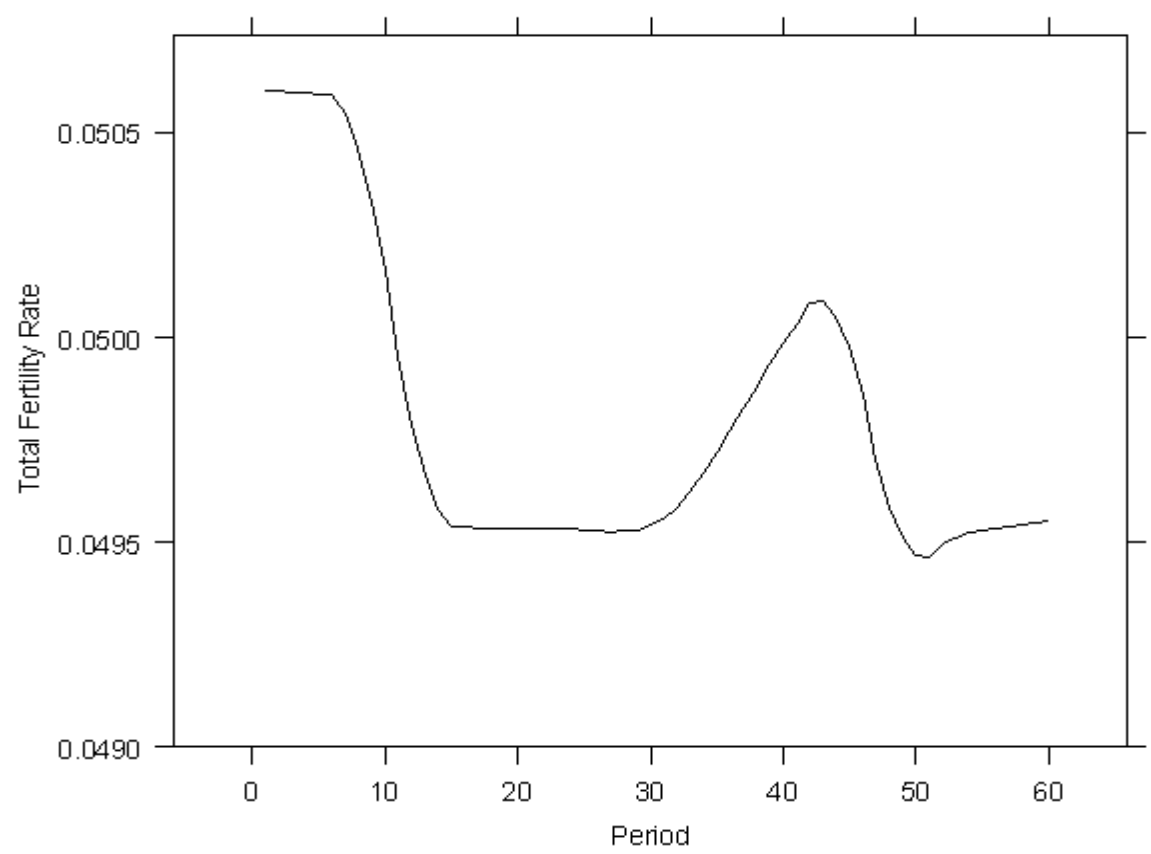

Figure 4. Dynamics of the total fertility rate resulting from women having children at age 35 instead of 24 .

After 10 periods near a stationary growth path, there is a sudden socio-economic change where instead of each 24 year old having 1.05 babies, it is each 35 year old which has 1.05 babies. In the short run, there is an immediate drop in the total fertility rate, as shown in Figure 4. It takes 20 years for the decreased number of children to affect the denominator in the total fertility rate (which starts at age 20) so total fertility rises. However, total fertility begins to fall as the initial drop in the number of children in period 10 affects the number of women of childbearing age in period 44 , resulting in a drop in the total fertility level. In the long run, fertility on average is lower, reflecting the considerations above.

The difficulty is thus to know whether the observed decline is a temporary or permanent phenomenon. In other words, are we observing a period similar to 
periods 10-30 above, or a new steady state? In general, the dynamics can be complex and will not normally be monotone, and it is not even certain that a new steady state will be reached.

\section{Conclusions}

Our results indicate that fertility rates are converging across countries. The convergence occurs both absolutely and conditionally: the coefficient on initial fertility is negative, regardless of the other variables we include in our regressions. We also find that the dispersion of the fertility rate seems to be falling, indicating that the cross-sectional variance is converging. An important caveat is that our paper focuses only on measured growth rates and does not attempt to look at comparative steady states (which is potentially a subject for future research). As illustrated through a simple example above, complex transitional dynamics in different countries could be influencing our convergence results.

\section{References}

Barro, R.J., \& Becker, G. (1988). A reformulation of the economic theory of fertility, Quarterly Journal of Economics 103(1), 1-25.

Barro, R.J., \& Lee, J.W. (1993). International comparisons and educational attainment, Journal of Monetary Economics 32, 3, 363-394.

Barro, R.J., \& Sala-i-Martin, X. (1995). Economic Growth. McGraw Hill, New York.

Baumol, W., Blackman, S.A.B., \& Wolff, E. (1989). Productivity and American Leadership: The Long View. MIT Press, Cambridge, Mass.

Becker, G. (1960). An economic analysis of fertility. In A. Coale (Ed.), Demographic and Economic Change in Developed Countries (pp. 209-231). Princeton: Princeton University Press.

Easterlin, R.A. (1966). On the relation of economic factors to recent and projected fertility changes. Demography, 3, 131-153.

Easterlin, R.A. (1989). Fertility. In The New Palgrave: Social Economics (pp. 77-89). New York: W.W. Norton.

Herbertsson, T.T. (1999). Sources of Economic Growth. Reykjavik: University of Iceland Press.

Holtz, V.J., Kleirman, J. A., \& Willis, R. J (1997). The economics of fertility in developed countries. In M.T. Rosenzweig \& O. Stark (Eds.), Handbook of Population and Family Economics (pp. 275-347). New York: Elsevier.

Kennedy, P. (1987). The Rise and Fall of the Great Powers. New York: Random House.

Keyfitz, N. (1977). Applied Mathematical Demography. New York: John Wiley.

Lee, K., Pesaran, M.H. \& Smith, R. (1997). Growth and convergence in a multi-

country empirical stochastic Solow model. Journal of Applied Econometrics, 12, 357-392. 
Leibenstein, H. (1974). An interpretation of the economic theory of fertility: Promising path or blind alley? Journal of Economic Literature, 12, 563-585.

Quah, D. (1993). Galton's Fallacy and tests of the convergence hypothesis, Scandinavian Journal of Econmics, 95, 427-443.

Schultz, T.P. (1997). Demand for children in low income countries, In M.T. Rosenzweig \& O. Stark (Eds.), Handbook of Population and Family Economics (pp. 349430). New York: Elsevier.

Smith, J. (1999). Healthy bodies and thick wallets: The dual relation between health and economic status. Journal of Economic Perspectives, 13(2), 145-166.

Temple, J. (1999). The new growth evidence. Journal of Economic Literature, 37, 112156.

Wahl, J.B. (1985). Fertility in America: Historical Patterns and Wealth Effects on the Quantity and Quality of Children. Ph.D. dissertation, University of Chicago.

World Bank (1993). The benefits of education for women, HRO Dissemination Notes, Human Resources Development and Operations Policy, No. 2, March 8. 


\section{Appendix A. Data}

- Population in 1998 (POP1998).

- Annual growth rate in population from 1978 to 1998 (AGR7898).

- Dependency ratio defined as population of age under 15 plus 65 and over per 100 people aged 15-64, in 1978 (DPR1978) and 1998 (DPR1998).

- Total fertility rate, defined as the number of births that a woman would have in her lifetime if, at each age, she experienced the birth rates occurring in the specified year. The total fertility rate is given for 1978 (TFR78) and 1998 (TFR98).

- The infant mortality rate, defined as deaths per 1,000 infants, in 1978 (IMR78) and 1998 (IMR98).

- The child mortality rate for 1998 , defined as deaths per 1,000 children aged 5 and under, separately for males (QM51998) and females (QF51998).

- The adult mortality rate for 1998, defined as deaths per 1,000 people between ages 15 and 59, separately for males (QM51998) and females (QF51998).

- The maternal mortality ratio, defined as deaths in childbearing per 100,000 mothers, for 1990 (MM90).

- Life expectancy at birth, in years, for 1978 for males (LEBM78) and females (LEBF78) and for 1998 for males (LEBM98) and females (LEBF78).

- GDP per capita in 1998, adjusted for purchasing power parity, in 1985\$ (GDP98).

- Average annual growth rate in GDP per capita, adjusted for purchasing power parity, between 1962 and 1997 (GDPGR6292) and between 1982 and 1992 (GDPGR8292).

- Average years of education for females over the age of 25 in 1990 (FEMED90) and the excess number of years for males relative to females (EDDIF90).

- Malnutrition stunting among males aged 5 and under in 1995 (MALNUTM95) and females aged 5 and under in 1995 (MALNUTF95).

- Percentage of children immunized against measles in 1987 (IMMUN87) and 1997 (IMMUN97).

- Health spending in 1995 as a percentage of GDP (HEALTH95), public health spending in 1995 as a percentage of GDP (PUBHEALTH95), and public health spending as a percentage of total public sector spending. 
Appendix B. Some Descriptive Statistics

\begin{tabular}{|c|c|c|c|c|c|}
\hline & Mean & Median & Maximum & Minimum & Std. Dev. \\
\hline POP1998 & 30,809 & 6,032 & $1,255,698$ & 1.94 & 118,855 \\
\hline AGR7898 & 0.39 & 0.32 & 0.99 & 0.01 & 0.29 \\
\hline DPR78 & 78 & 82 & 115 & 43 & 18 \\
\hline DPR98 & 68 & 64 & 108 & 39 & 19 \\
\hline FERDIFF & -1.25 & -1.2 & 1.02 & -4.05 & 0.95 \\
\hline TFR78 & 4.72 & 5.15 & 8.49 & 1.51 & 2.02 \\
\hline TFR98 & 3.47 & 2.98 & 7.6 & 1.15 & 1.77 \\
\hline IMR78 & 73.75 & 65 & 263.2 & 7.9 & 51.4 \\
\hline IMR98 & 46.61 & 33.6 & 169.5 & 4.3 & 38.43 \\
\hline IMRDIFF & -27.14 & -22.4 & 11.3 & -160.2 & 21.78 \\
\hline QF15591998 & 199 & 133 & 7,234 & 49 & 155 \\
\hline QF51998 & 64.84 & 38.28 & 257.43 & 5.12 & 61.76 \\
\hline QM15591998 & 269 & 218 & 774 & 92 & 149 \\
\hline QM51998 & 72.46 & 46.47 & 277 & 6.15 & 65.9 \\
\hline MMR90 & 401 & 155 & 1,800 & 0 & 479 \\
\hline LEBF78 & 62.19 & 64.25 & 79.3 & 32.5 & 11.97 \\
\hline LEBF98 & 67.44 & 71.99 & 82.93 & 38.68 & 11.98 \\
\hline LEBM78 & 57.73 & 59.75 & 73.4 & 30 & 10.56 \\
\hline LEBM98 & 62.77 & 66.22 & 76.82 & 35.83 & 10.62 \\
\hline GDP78 & 3,959 & 2,459 & 15,440 & 315 & 3,763 \\
\hline GDP98 & 5,213 & 2,949 & 17,945 & 408 & 5201 \\
\hline GDPGR6292 & 1.77 & 1.85 & 6.71 & -2.24 & 1.55 \\
\hline GDPGR8292 & 0.65 & 0.73 & 6.03 & -5.65 & 2.23 \\
\hline FEMED90 & 4.62 & 4.43 & 11.57 & 0.27 & 3 \\
\hline EDDIF90 & 1.06 & 0.86 & 3.55 & -1.06 & 0.89 \\
\hline MALNUTF95 & 27.52 & 25.5 & 62.7 & 1.8 & 14.45 \\
\hline MALNUTM95 & 29.11 & 27.3 & 65.7 & 1.8 & 14.54 \\
\hline IMMUN87 & 62.47 & 65 & 100 & 6 & 24.25 \\
\hline IMMUN97 & 81.36 & 89 & 100 & 18 & 18.99 \\
\hline HEALTH95 & 5.58 & 5.4 & 14 & 0.3 & 2.47 \\
\hline PUBHEALTH95 & 3.55 & 2.85 & 22.8 & 0.2 & 2.61 \\
\hline
\end{tabular}




\section{Appendix C. Simple Model of Transitional Fertility}

This appendix outlines a simple model of transitional fertility, which was used for simulating the dynamics in Figure 4.

Let $n(t, a)$ be the number of individuals of age $a$ at time $t$. This age-specific population is related to past births by:

(eq. 1) $n(t, a)={ }_{a} p_{t-a} n(t-a, 0)$

where ${ }_{a} p_{t-a}$ is the probability of an individual at time $t-a$ living additional $a$ years. By assuming that all women have children at the same age $\hat{a}$, we get:

$$
\text { (eq. 2) } \quad n(t, 0)=b(t, \hat{a}) n(t, \hat{a})
$$

If the population curve is downward sloping as a function of age (as occurs in steady states with positive death and positive population growth rates), the number of newborn babies falls as $\hat{a}$ increases with a constant birth rate.

To determine the long run growth rate, $g$, we note that a steady state solution with growth (if achieved) will have the form:

$$
\text { (eq. 3) } n(t, a)=(1+g)^{t} f(a)
$$

where $f(a)$ is a stationary population profile. If we have such a steady state solution, we note that (using equation (3) in (2)):

$$
\text { (eq. 4) } \quad f(0)(1+g)^{t}=b(t, \hat{a})(1+g)^{t} f(a)
$$

so that the relationship between $f(0)$ and $f(a)$ does not vary over time as long as the birth rate is independent of time in steady state. Furthermore:

$$
\text { (eq. 5) } \quad f(a)(1+g)^{t}={ }_{a} p_{t-a}(1+g)^{t-a} f(0)
$$

so that:

$$
\text { (eq. 6) } \quad f(a)={ }_{a} p_{t-a}(1+g)^{-a} f(0)
$$

By using equation (4) for births above we get:

$$
\text { (eq. 7) } f(a)={ }_{a} p_{t-a}(1+g)^{-a} b(\hat{a}) f(a)
$$

which determines $g$ endogenously based on $b$ and the survival probabilities $p$. In general, this means that unless there is an increase in fertility of older women, the steady state rate of population growth will be lower. For instance, in the special case where the survival probability to childbearing age is 1 , we have:

$$
\text { (eq. 8) } g=b(\hat{a})^{\gamma}-1
$$

where $\gamma=1 / a$ which is smaller due to the compound effect of growth. This effect however may be quantitatively small and we expect that transitional declines in fertility ordinarily to be larger than the steady state effects because the population falls below its initial steady state level along the transition path. There is, in general, no guarantee that models of this type have a long-run steady state. 